\title{
Voluntary Observing Ship and Marine Scientific Research under the Law of the Sea
}

\author{
Hong Chang
}

Historical introduction. Vessel observation, as a significant part of stereoscopic monitoring of marine environment, has gained wide recognition and plays a crucial role in marine scientific research for centuries. In the beginning, the safety of navigation was the focal point of weather observing at sea. As early as 1853, Matthew Fontaine Maury of the U.s. Navy proposed the conveying of an international conference to coordinate the establishment of uniform observation systems at sea. ${ }^{1}$ After that, most attending countries arranged their ship to transmit the observations to shore. However, during the past decades, with the further development of marine science and marine technology, combined with the threat of global warming and other environmental disasters, the requirements of large scale and real-time observations were more and more expanded. ${ }^{2}$ A well-organized system for collecting observations at sea is generally considered as being necessary today. The Joint Technical Commission for Oceanography and Marine Meteorology (Jсомм), an expert intergovernmental organization, which is co-organized by the World Meteorological Organization (WMO) and the Intergovernmental Oceanographic Commission (IOC), consolidates and coordinates the observations, data management and service system of oceanography and marine meteorology. ${ }^{3} \mathrm{JCOMM}$ is composed of the Observations Programme Area, the Data Management Programme Area (OPA) and the Services Programme Area plus two Cross Cutting Task Teams on Satellite Data Requirements and Capacity Building. ${ }^{4}$ The OPA is primarily responsible for the development, coordination and maintenance of the multi-mode marine observations by the means of global cooperation. The Ship Observation

1 For further details, see http://www.bom.gov.au/jcomm/vos/vos.html.

2 For more information, see http://www.bom.gov.au/jcomm/vos/documents/vos_brochure. pdf.

3 For information on the work of JСОмм, see http://www.jcomm.info/index.php?option=com_ frontpage\&Itemid $=1$.

4 For further details, see http://www.jcomm.info/index.php?option=com_content\&task=view \&id $=89 \&$ Itemid $=97$. 
Team (sot) is a subdivision of the OPA. Its main component is the Voluntary Observing Ships (vos) Scheme. ${ }^{5}$

How the vos scheme works. The data collected by vos are used for the preparation of forecasts and warnings to help route ships and avoid severe weather conditions, to monitor the state of the oceans, for climatological data banks serving many purpose, and to build long-term records to monitor changes in the climate of the earth. ${ }^{6}$ These data pertains to the atmosphere above the sea (temperature, dew point, cloud, weather, visibility and pressure) and to the surface of the sea (temperature, waves, currents and ice). ${ }^{7}$

The members of the wmo recruit all the ships of the vos scheme. The representative responsible for recruiting is the Port Meteorological Officer (PMO) who plays a critical role in the running of the vos scheme. The functions of the PMO also comprise maintaining accurate records of the ships, regularly visiting the ships, providing relevant service regardless of the ship's nationality and country of recruitment, and so on. ${ }^{8}$ All the members of the vos Fleet, no matter what are the nationalities of the ships and the country of recruitment, could share the observations around the related routes. It means that vessels offer their observations in return for obtaining the forecasting, warning service, and instrumentations. Besides, there are no direct costs for attending vessels. Communication charges for the transmission are exempt. ${ }^{9}$

Data management. Traditionally, Voluntary Observing Ships have measured and reported the atmospheric and sea surface conditions which are needed for meteorological forecasting. ${ }^{10}$ There are two ways how the vos data flows: observations are transmitted in real time, and observations are recorded in

5 For further details, see http://www.jcomm.info/index.php?option=com_content\&task=vi ew\&id=21\&Itemid $=38$.

6 See J. Ashley Roach, Defining Scientific Research: Marine Data Collection, in Myron H. Nordquist, LaW, Science \& OCean Management 541-574, 557 (2008).

$7 \quad$ Ibid.

8 For more introduction and detailed functions of рмо, see, http://www.bom.gov.au/ jcomm/vos/pmo.html.

9 For the general information, see, http://www.bom.gov.au/jcomm/vos/vos.html; and http://www.bom.gov.au/jcomm/vos/vos.html, at 3. For the situation of USA, on the official website, available at http://www.vos.noaa.gov/us_vos.shtml, it is said that, "vos operates at no cost to the vessel, with communication charges, observing equipment and reporting supplies furnished by the National Weather Service."

See http://gosic.org/goos/VOS-data-flow.htm\#Voluntary\%2oObserving\%2oShips. 
paper or electronic logbooks. ${ }^{11}$ In the first one, real time observations are transmitted to the National Meteorological and Hydrological Services (NMHSs) by using Geostationary Technology Satellite (GTS). Some NMHSs keep an archive of the data extracted from the GTS. ${ }^{12}$ In regards to the latter, marine meteorological observations are recorded on board in special registers (logbooks), which are provided by national meteorological services. Then the PMO of the recruiting country collects the logbooks, transfers the observations from the logbooks to a magnetic media in a standard format, sends the data to global collecting centers in Germany and the United Kingdom, approximately once every three months. The two centers provide data to eight members who are responsible for the preparation of climatological summaries. ${ }^{13}$

New situation. The variables observed by vos originally regard to the air or the sea surface, like dry-bulb temperature, dew-point temperature, sea surface temperature, air-sea temperature difference, visibility, weather, wind direction and speed, pressure, cloud, and waves. ${ }^{14}$ Later, with the development of science, awareness grew that the most challenging scientific problems encompass two or more of the environmental sciences. Development of a theory of climate will require treating the oceans and atmosphere as a thoroughly interacting system, ${ }^{15}$ since the atmospheric circulation cannot be understood apart from considering the ocean, and vice versa. ${ }^{16}$ Practically, it is far from enough to conduct climate research only by considering the atmosphere. A new situation therefore developed that the scientists began to do climate research by using marine factors, say, taking some marine data and sea water samples from the ocean on vos, like sea surface salinity, dissolved oxygen and seawater $\mathrm{CO}_{2}$ partial pressure $\left(p \mathrm{CO}_{2}\right) \cdot{ }^{17} \mathrm{In}$ this regard, the most prominent activities are the underway $\mathrm{CO}_{2}$ measurements which now is conducted by many ocean research institutions. The oceans are the largest sustained sink of anthropogenic carbon dioxide from the atmosphere. Therefore, understanding the physical, chemical

11 See, Elizabeth C. Kent, et al., The Voluntary Observing Ship Scheme, available at https://abstracts.congrex.com/scripts/jmevent/abstracts/FCXNL-ogAo2a-1664333-1cwp4a07_revi.pdf, at 1. See the data flow diagram on http://www.bom.gov.au/jcomm/vos/ dataflow.html.

12 Kent, et al., supra note 11, at 2.

13 For more detailed information about data management, see, http://www.bom.gov.au/ jcomm/vos/vos.html; and http://gosic.org/gcos/vos-program-overview.htm.

14 See http://gosic.org/goos/VOS-data-flow.htm\#Voluntary\%2oObserving\%2oShips

15 Thomas A. Clingan, The Law of the Sea: Ocean Law and Policy 435 (1994).

16 Ibid., at 435 .

17 Research details see T. Steinhoff and A. Körtzinger, vos-based p $\mathrm{CO}_{2}$ measurements in the North Atlantic Ocean - does the DpCO2 change?, available at http://ioc3.unesco.org/ioccp/ pCO2_workshop/Posters/Steinhoff_SOCOV.ppt. 
and biological processes involved, feedback effects, and the future of this sink is critical for reducing uncertainty of climate change. Scientists normally outfit those vos with automated carbon dioxide analyzers as well as thermosalinographs (TSGs) to measure the temperature, salinity and partial pressure of $\mathrm{CO}_{2}$ $\left(\mathrm{pCO}_{2}\right)$ in surface water and air in order to determine the carbon exchange between the ocean and atmosphere. ${ }^{18}$

The way that the scientists or the equipment can get on the vessel is quite simple: negotiating with the shipping company and the captain. This means no one would apply for the consent of the likely coastal States (according to the shipping routes) before the scientists and the equipment getting on the vessel to take measurements from the ocean. ${ }^{19}$ This practice has already existed for decades and not too much attention has been paid to it. If the company or the captain agrees, the scientists are allowed to embark or they contact with the chief engineer to emplace the equipment. The measurements would be conducted along the shipping routes. With respect to the shipping company, some advanced clients require the commercial ships to wear a "green label," which means, in some circumstances, friendly environmental ships are more popular. Even more important, captains and engineers who care about the research of climate change are willing to promote and facilitate the development of climate research. All these make the measurements from ocean on the vos more and more common. However, the way of data collection varies from the meteorological data collection as described in the foregoing. Neither the PMO nor transmitting the data to the National Meteorological and Hydrological Services (NMHSs) gets involved. The scientists who deploy the equipment have their own system of receiving the data from satellite. ${ }^{20}$ If the data received is not continuous, scientists would know that something is wrong with the equipment. Either then they fix the problem or they can inform the chief engineer to deal with it. In plain terms, the shipping company or the captain voluntarily carry scientists or equipment for conducting measurements in the ocean. They provide necessary assistance to the scientists or keep an eye on the running of the automatic equipment, however, they have nothing to do with the data collection. ${ }^{21}$

The marine environment, which is both important for marine science and the law of the sea, is defined by Soons "as covering the water column, the

\footnotetext{
18 See http://www.pmel.noaa.gov/co2/story/Volunteer+Observing+Ships+\%28VOS\%29.

19 Conversation with Professor Arne from IFM-Geomar.

20 Conversation with Tobias Steinhoff who was a doctoral candidate under the supervision of Professor Arne.

Ibid.
} 
seabed and subsoil, and the atmosphere immediately above the sea." ${ }^{22}$ As stated above, the variables, both relevant to the ocean and meteorology are collected on vos from the water surface, the underwater, the atmosphere immediately above the sea as well as the atmosphere non-immediately above the sea. The former ones, according to the definition, are the components of the marine environment. That is to say, these variables are collected in the marine environment. As long as the marine environment is involved, the situation might be complicated because of the existence of the "Constitution for the Oceans"23 United Nations Convention on the Law of the Sea (LOS Convention) which is an important contribution to the law of the sea. Traditionally, the law of the sea deals with the activities on and in the oceans, which were tied to the environment in which they take place. The Los Convention sets out principles and norms for regulating the conducts that are relevant to maritime issues. In the Convention's preamble, it is expressly stated that "Recognizing the desirability of establishing through this Convention, with due regard for the sovereignty of all States, a legal order for the seas and oceans which will facilitate international communication, and will promote the peaceful uses of seas and oceans, ..." Thus it can be seen that the goal of the Los Convention is to provide the legal order for the uses of the seas and oceans. Since taking measurements on vos from the oceans constitutes an ocean use which may affect maritime areas within and beyond the limits of national jurisdiction, legal issues therefore should be analyzed on the basis of the Los Convention.

\section{Relationship between the Ocean Measurements on vos and Marine Scientific Research}

It should be noted, firstly, that the newly emerging practice of ocean measurements on vos are distinguished from traditional data collection activities on vos in terms of legal status. With respect to the vos scheme, during the Los Convention negotiations of the third committee, the Secretary-General of the

\footnotetext{
22 A.H.A. Soons, Marine Scientific Research and the LaW of the Sea 124 (1982). Also see, Katharina Bork, et al., The legal regulation of Floats and Gliders-In quest of a new regime? 39 OCEAN Development AND International LAW 303 (2008).

23 Statement of Ambassador Tommy Koh of Singapore, President of the Third United Nations Conference on the Law of the Sea, at the final session of the Conference at Montego Bay, Jamaica, on 11 December 1982; reprinted in UN Pub. Sales No. E.83.V.5, 1983, at xxxiii. Excerpted from Satya N. Nandan, An Introduction to the 1982 United Nations Convention on the Law of the Sea, in Davor Vidas et al., (eds.) Order for the Oceans at the TURN OF THE CENTURY (1999).
} 
World Meteorological Organization expressed the concern that some provisions on marine scientific research might have direct consequences on activities conducted by the World Meteorological Organization over the oceans. Specifically, the vos Scheme was pointed out. The chairman of the Third Committee, realizing that the adequate marine meteorological data coverage, including that from areas within the exclusive economic zone, was indispensable for timely and accurate storm warnings for the safety of navigation and for the protection of lives and property in coastal and offshore areas, expressed that

the pertinent provisions of the second revision of the text on marine scientific research would not create any difficulties or obstacles hindering adequate meteorological coverage from the ocean areas, including areas within the exclusive economic zone since such operational and research activities have already been recognized as routine activities within the terms of reference of the World Meteorological Organization and are of common interest of all countries with undoubted universal significance. ${ }^{24}$

While it is decided that the collection of marine meteorological data is not marine scientific research regulated by Part XIII of LOS Convention, ${ }^{25}$ this newly emerging practice of ocean measurements on vos may face a different situation.

\section{$1 \quad$ What is Marine Scientific Research}

Since there is no definition of the term "marine scientific research" in the Los Convention, various views toward the definition therefore are expressed and most of them can be sorted into two categories that focus on distinct perspectives. Whereas one considers the term under the context of the legal regime whose purpose is indicating which activities are governed by the regime of MSR and which are not, ${ }^{26}$ the other one stresses the peculiarities from the scientific point of view ${ }^{27}$ that places more weight on the nature and essence of the relevant activities in abstract terms. According to the first category, it is stated:

Marine scientific research is the general term most often used to describe those activities undertaken in the ocean and coastal waters to expand

24 See Official Records of the United nations Third Conference on the Law of the SeA, Volume XIV, at 102-103, 133-134. Excerpted from Roach, supra note 6, at 203.

25 Ibid.

26 Soons, supra note 22, at 5 .

27 Ibid. 
scientific knowledge of the marine environment. It includes oceanography, marine biology, fisheries research, scientific ocean drilling and coring, geological/geophysical scientific surveying, as well as other activities with a scientific purpose. ${ }^{28}$

Thus, it can be seen that the disciplines constitute marine scientific research contain marine biology, ${ }^{29}$ chemistry, ${ }^{30}$ physics, ${ }^{31}$ geology, ${ }^{32}$ meteorology, ${ }^{33}$ hydrograph ${ }^{34}$ and oceanography. ${ }^{35}$

Turning then to the second one, the definition has been based on the general notion of research, which means diligent and systematic inquiry or investigation into a subject in order to discover facts or principles. ${ }^{36}$ The ordinary meaning of the term "scientific research" is the investigation of a phenomenon, question, or problem conducted by the means and methods of science. ${ }^{37}$ Marine scientific research may be regarded as such investigation concerned with the marine environment which is commonly understood as covering the water column, the seabed and subsoil, and the atmosphere immediately above the sea. ${ }^{38}$ Therefore, marine scientific research can be defined as "any

28 J. Ashley Roach and Robert W. Smith, Excessive maritime Claims 248 (1994).

29 Marine biology is concerned with the living organisms of the sea, such as marine microbes, plankton, benthic organisms, ..., marine reptiles and marine mammals. Excerpted from Florian H. Th. Wegelein, Marine Scientific Research 12 (2005).

30 Marine chemistry deals with the chemical properties of the sea water. Ibid.

31 Marine physics or physical oceanography is concerned with the physical characteristics of sea water. Ibid.

32 Marine geology is concerned with the tectonic situation of the sea floor, with submarine topography, terrestrial magnetism and paleomagnetism, gravity, quake and elastic wave, and sedimentation. Ibid.

33 Marine meteorology is concerned with the interactions and mutual influence between the oceans and the atmosphere. Ibid.

34 Hydrography is concerned with the aspects of navigation of the sea. Mapping of the sea floor, depth soundings, wreck search and tide schedules are the most prominent services for navigators. Ibid.

35 Oceanography, in the scientific community, denotes the holistic study of the marine environment, namely, the system of oceans and atmosphere from possible views of the marine sciences: " the scientific studies of ocean, its boundaries and bottom topography, its physics and chemistry and of its marine organisms, including the interrelations and interactions." Ibid. See WE G E LEIN, supra note 29, at 12-17.

36 Mirjam Skrk, The Prospects of Marine Scientific Research in the Contemporary Practice of States, in Budislav Vukas, (ed.), Essays on the New LaW of the Sea 340-368, 344 (1990).

37 Katharina Bork, The legal regulation of Floats and Gliders-In quest of a new regime? 39 Ocean Development and International LaW 303 (2008). Also see, Soons, supra note 22 , at 124 .

See Soons, supra note 22, at 124. 
investigation of a phenomenon occurring in the seabed or the subsoil, the water column, or the atmosphere directly above the water."39

Do the Ocean Measurements on vos Constitute Marine

Scientific Research?

As the foregoing analyzed, the emerging practice of ocean measurements on vos has nothing to do with the framework of the wMo. Neither the data collection purpose nor the data management is as the same as the vos Scheme, other than the use of vos fleets. Based on the ordinary meaning of scientific research, ${ }^{40}$ these vos measurements and observations can fall within the scope of scientific research. Furthermore, in light of the definition of marine environment, ${ }^{41}$ the conduct of measuring the parameters and taking samples from the ocean or from the atmosphere immediately above the sea ${ }^{42}$ can be considered as activities in marine environment. In that case, consequently, the ocean measurements and observations on vos can be deemed as marine scientific research. ${ }^{43}$

Compared with the research vessel $(\mathrm{R} / \mathrm{V})$, vos offers a simple and convenient platform for scientists to conduct marine scientific research.

Research vessel. Under the Los Convention, other than the consent regime, Articles 248, 249 and 250 made extremely clear the duties of the research party.

39 Bork, supra note 37 , at 304.

$40 \quad$ See Skrk, supra note 36.

41 See Bork, supra note 37.

42 A research result shows these kinds of measurements. It is stated: [T] he following parameters are measured in continuous underway mode: Sea surface temperature, Sea surface salinity, Dissolved oxygen, Chlorophyll (fluorescence), Atmospheric and seawater $\mathrm{pCO}_{2}$. Discrete water samples are taken for measurement of the following parameters (approx. 7 cruises annually): Dissolved inorganic carbon (DIC), Alkalinity, Nutrients, Total organic carbon and nitrogen (TON, TN), $\delta^{13} \mathrm{C}-\mathrm{DIC}$, Salinity (for calibration of the TSG unit), Chlorophyll-a (for calibration of the fluorescence probe), Particulate organic carbon and nitrogen, ${ }^{17} \mathrm{O}-\mathrm{O}_{2}$ for productivity estimates (cooperation with Paul Quay, Univ. Washington, Seattle/USA, start in 2007). More details, see Steinhoff and Körtzinger, supra note 17.

43 Some parameters, like surface wind speed and direction, air temperature, cloud, wave, weather and visibility information, which measured by vos are not in the marine environment. Therefore, the conduct cannot be deemed as marine scientific research. In this thesis, only the part, which is deemed as marine scientific research, will be analyzed. The details about what other parameters can be achieved by vos see Kent et al, supra note 11, at 1. 
Article 248 is about the duty to provide information to the coastal State, ${ }^{44}$ combined with Article 249 that specifies the duty to comply with certain conditions. ${ }^{45}$ Article 250 makes reference to the communications concerning marine scientific project, which should be made through appropriate official channels, unless otherwise agreed. ${ }^{46}$ It can be seen that conducting marine scientific research in the exclusive economic zone or on the continental shelf of a coastal State, the procedures and the requirements are highly complicated and sometimes extra requirements have been put forward as well, like two cruises in two years. ${ }^{47}$ It is said that "not less than six months in advance of the expected starting date of the marine scientific research project" ${ }^{\prime 48}$ to provide the full description of the project. Practically, at least one or two years before the starting date, researchers have to prepare for the cruise, including applying for the funding. ${ }^{49}$

Voluntary Observing Ship. As the foregoing analysis show how vos scheme works, the most attractive consideration for scientists is that there is no need to secure the consent from the coastal State for the measurement in the ocean during the vos cruise. This means it is much easier for scientists to take measurements from the ocean on vos rather than a research vessel. Leaving all the application processes out makes scientists more than happy to conduct marine

44 See unclos, supra note 1, Myron H. Nordquist (ed.), United nations Convention on The Law of The Sea 1982: A Commentary, Volume iV Articles 192 to 278 Final ACt, AnNeX Vi 526 (1989), Article 248. It is included that the nature and objectives of the project, the method and means to be used, the precise geographical areas in which the project is to be conducted, the expected date of first appearance and final departure of the research vessels, the name of the sponsoring institution, its director and the person in charge of the project, and the extent to which it is considered that the coastal state should be able to participate or to be represented in the project.

45 Ibid., at 537. These conditions including, ensuring, if requested, the right of the coastal state to participate or represented in the project without any payment or obligation to contribute towards the costs of the project; providing the coastal state, if requested, with preliminary report, final results and the conclusions after the completion of the research; providing the coastal state, if requested, access to all data and samples and the data which may be copied and samples which may be divided without detriment to their scientific value; providing the coastal state, if requested, the assessment of such data, samples and research results or assistance in their assessment; ensuring the research results are made internationally available; informing the coastal state immediately of any major change in the research program; and the last one is removing the scientific research installations or equipment once the research is completed, unless otherwise agreed.

46 Ibid., at 554 .

47 Conversation with Professor Arne.

48 Art. 248, Los Convention.

49 Conversation with Professor Arne. 
scientific research on the vos if it could meet their research requirements. Furthermore, there are some other advantages which make the vos scheme more attractive for scientists as well, like most of the vos are commercial ships, ${ }^{50}$ the sailing routes are comparatively regular and frequent. This is beneficial to some kinds of marine scientific measurements, like seawater temperature, salinity and ocean current. Additionally, cutting the cost, this may be not the primary factor to attract scientist, however, this can sometimes make a little impact.

As the LOS Convention is silent on the definition of marine scientific research as well as what it is constituted, it thus denotes that the Los Convention is incapable of clarifying what activities should be subject to the legal regime of marine scientific research. Moreover, within the vos scheme, there is another way of operation that is totally different from the legal regime of marine scientific research established in Los Convention. Therefore, there must be a vacuum zone where marginal case happens there. That would be, on the one hand, for the sake of climate research, scientists would like to do all the kinds of observation including in the ocean on vos while there are no legal norms regulating those activities. On the other hand, the original intention of vos scheme is mainly for atmospheric weather forecasting and climate change studies ${ }^{51}$ which could conduct research in the atmosphere freely without the limitation of borders. All of these make it possible to lead the marine scientific research that is conducted on vos into an awkward position. Is it legal or illegal? How can it be protected?

The Los Convention, in Articles 245 and 246 make it extremely clear that marine scientific research in the territorial sea, exclusive economic zone and on the continental shelf should be conducted under the consent of the coastal States. In a literal sense, the ocean measurements on vos that are taken along the shipping routes cannot be seriously argued that the conduct is legal by virtue of the Los Convention. The consideration about the feasible consequences becomes applicable since the Los Convention in Articles 27-32 codify different rules between merchant ships and government ships which are operated for non-commercial purposes. While government-owned vessels that are operated for non-commercial purposes enjoy immunities from boarding by other States on the high seas or other marine zones of coastal States, ${ }^{52}$ the merchant or civilian vessels may not enjoy these immunities to the same extent. ${ }^{53}$

\footnotetext{
$5^{0} \quad$ Kent et al, supra note 11 , at 1.

51 Available at http://gosic.org/gcos/VOS-program-overview.htm

52 Art. 32 , Los Convention.

53 Arts. 27 and 28, Los Convention. See Montserrat Gorina-Ysern, An International Regime for Marine Scientific Research 16 (2003).
} 
Similarly, the U.s. Coastal Guard issues that while oceanographic vessels so designated are exempt from most of the inspection laws of the U.s., as merchant vessels, they are subject to manning requirements under U.s. law. ${ }^{54}$ Namely, for commercial ships, as the majority composition of vos fleet, the factor of nonimmunities is important to bear in mind. In some cases, it is horrible that the coastal States' domestic implementation of the international law applicable to foreign vessels for breaching of coastal State's regulations. The measures are beyond the purport of Article 253 which requires the coastal State to order the suspension or cessation of the MSR activities, including the impounding of the vessel and its scientific equipment, very large fines, and imprisonment of the chief scientist or the master of the vessel. ${ }^{55}$ That make ocean measurements on vos extremely dangerous. It happens sometime that coast guards get aboard to do routine inspection, whereas they may go for whether there is marine pollution, drug smuggling or other breach of regulations since they have no idea about the use of the scientific instruments and none of the crews or the scientists would mention it. ${ }^{56}$ It is therefore concluded that a thorough protection from the legal ground is demanded. Some regulations are supposed to be worked out and make it black and white to ensure that there are legal basis for both research States and coastal States.

\section{Legal Analysis}

Ocean Measurements Conducted on vos are Pure Scientific Research It is well known that research that is "in accordance with this Convention (LOS Convention) exclusively for peaceful purposes and in order to increase scientific knowledge of the marine environment for the benefit of all mankind" can be considered as pure scientific research, which is promoted by the LOS Convention. In the case of ocean measurement on vos, the measurement of marine data and the analysis of marine sample are effective means to investigate the climate change that is for the benefit of all mankind. It has come to light that climate change is more and more close to the lives of all the mankind. As the United Nations Secretary General has said, it is the major, overriding environmental issue of our time, ${ }^{57}$ and represents one of the greatest social

\footnotetext{
54 Excerpted from GoRINA-YSERN, supra note 53.

55 See Gorina-Ysern, supra note 53, at 17-18.

56 Conversation with Professor Arne.

57 See http://www.unep.org/climatechange/Introduction/tabid/233/language/en-US/De fault.aspx.
} 
and economic threats facing the planet as well. ${ }^{58}$ In terms of the research purpose though, it is a subjective criterion. What make the coastal States most worried about are the exploration of nature resource and the territory security.

\section{A Unrelated to Natural Resources Exploitation}

Marine natural resources include living resources and non-living resources. Among the living resources, the costal State is more alert to fish catches which is threatened by Illegal, unreported, and unregulated (IUU) fishing and over fishing whenever an unknown vessel shows up whether for research or not. With respect to the non-living resources which are constituted, most importantly, by the mineral resources that are either dissolved in sea water, resting on the ocean floor, or found underneath it. ${ }^{59}$ The initial period of non-living resources exploration that concerns the coast State most is to investigate the geographical and geological conditions of the ocean floor to obtain detailed information on offshore resources. ${ }^{60}$ Learning the geographical and geological information of the ocean floor is a sophisticated research process,let along that surveys of potential resources need to be carried out for a considerable time and the technologies have already gone so advanced that the extra precision instruments are required. Against this background, the variables frequently taken on vos, like sea surface salinity, dissolved oxygen and seawater $\mathrm{CO}_{2}$ partial pressure $\left(p \mathrm{CO}_{2}\right),{ }^{61}$ are far from meeting the technical requirements of those forgoing applications. Other than that it is obvious that the emphasis of the measurements on vos is just the marine data and sample, rather than catching fishes. Therefore, in this view of perspective, anxious of the coastal State seems superfluous.

\section{B $\quad$ Not Endanger the Coastal State's National Security}

Every country regards the maintenance of its military security as a matter of highest national priority. It is hard to image that oceanographic research has

58 Available at http://ec.europa.eu/environment/climat/home_en.htm.

59 Roger H. Charlier and Constance C. Charlier, Ocean Non-Living Resources: Historical Respective on Exploitation, Economics and Environmental Impact, 40 INTE RNATIONAL JOURNAL OF Environmental Studies 123-134 (1992). It is said that the dissolved minerals include salt, bromine and magnesium, iodine, potassium, brines, and suspended matter. The minerals from the sea floor include sand, gravel, shells, tin, phosphorus, sulphur, and polymetallic nodules. The minerals beneath the ocean floor include hydrocarbons, coal and others.

6o Teruhis Tsujino, Exploration Technologies for the Utilization of Ocean Floor Resources: Contribution to the Investigation for the Delineation of Continental Shelf, 24 QUARTERLY Review 68 (2007).

61 For research details, see Steinhoff and Körtzinger, supra note 17. 
no potential military application. ${ }^{62}$ Whenever an oceanographer measures depth, water temperature, pressure or salinity anywhere in the ocean, the collected data could be of some possible use to navies. ${ }^{63}$ Even worse, some conducts of military intelligence or subversive activities under the guise of, or along with, marine scientific research. ${ }^{64}$ It is thus highly understandable that the most secure action for a coastal State would appear, such as restricting or preventing the access of the information about nearby waters. As for the respect of marine measurement on vos, it should be born in mind that the purpose is for climate change studies, even though some of the variables taken by vos may seem suspicious. However, it should not be ignored that there is, as mentioned before, a data management system in vos scheme as well as the marine measurements on vos. In terms of the marine data collected on vos, each time after one research program on vos, mostly one or two years, researchers would make the data open to public through various channels, ${ }^{65}$ like putting the data on internet ${ }^{66}$ which is beneficial to whole science circles or publishing papers ${ }^{67}$ which is considered as scientific literature that as an important source of conducting marine scientific research. ${ }^{68}$ Whereas admittedly, military intelligence data would not go to public field and still further unlikely to born published articles that are accessible to the whole world. It is generally regarded that "publication of the research findings in the open scientific literature is one indication of the distinction between open and proprietary research." 69

62 See Warren S. Wooster, Freedom of Oceanic Research 161 (1973).

63 Ibid.

64 See Soons, supra note 22, at 32.

65 Conversation with Professor Arne.

66 For examples, see http://www.ioccp.org/UW.html and http://www.carboocean.org. The former one offers coordination service for the ocean carbon community. The latter one is for marine carbon sources and sinks assessment.

67 Such as, Steinhoff and Körtzinger, supra note 17, and Assessment of the current ocean carbon sink and its implications for climate change and mitigation, available at http://www .oceanobsog.net/plenary/files/Koertzinger_CarbonSink_3Ac_vfinal.pdf. The authors both conduct marine scientific research on voluntary observing ships which are named M/V Falstaff (Wallenius Lines, Sweden) and M/V Atlantic Companion (Atlantic Container Lines, USA).

68 There are two phases which constitute marine scientific research: collecting data on the one hand and interpretation of those data on the other. In many cases, data that already exist can be made use of conducting marine scientific research and the important source of already existing data is the scientific literature. For more information, see Soons, supra note 22, at 16 .

69 See Wooster, supra note 62, at 168. For the same view, also see Soons, supra note 22, at 7. It is said that "Like is the case with fundamental marine scientific research, the results 
Still everything has an exception. It is however irrational that uses denial to safeguard the uncertain "endangered" interests even though it is of doubt whether the contributions of researchers are all for science's sake. A set of legal regime about vos marine scientific research is supposed to protect the "science sake" and prevent from coast States' interests getting dangerous. Furthermore, as for the conduct of ocean measurements on vos, all the requirements and qualifications by virtue of Los Convention will be observed. Under the view that the tendency towards promoting marine scientific research and benefiting all the human beings is overwhelming, the potential exceptional case should not be the excuse of holding up the pace of science development.

\section{2}

\section{Notifying Regime}

Under UNCLOS Article 246, it is expressly provided that marine scientific research shall be conducted with the consent of the coastal State in the exclusive economic zone and on the continental shelf. Nevertheless one thing should still be bore in mind that the consent regime is only applicable to the circumstance that when the research is conducted in EEZ or on the continental shelf of the coastal State. In the territorial sea, the coastal State enjoys sovereignty which denotes the legal status of the territorial sea is almost alike the internal waters (except for the innocent passage regime). As a consequence of sovereignty, access of foreign vessels to the territorial sea and internal waters specifically for the purpose of conducting marine scientific research is subject to the complete authority of the coastal State. ${ }^{70}$ The coastal State may enact any regulation, either requires of prior consent or impose any condition, at its own discretion. ${ }^{71}$ It would be thus much more complex to conduct marine scientific research in the territorial sea or internal waters. Furthermore as mentioned before, the commercial vessels are exempt from the immunities. The reason why this consideration should be made is that the commercial ships, which in most cases constitute the vos fleet, normally would enter the respective Ports of the coastal State that means those ships not only go across the territorial sea but go into the internal water as well.

According to Soons, notifying regime was defined as "Consent of the coastal State would not required, but those conducting the research would have to notify the coastal State and comply with certain internationally agreed

of such research are generally published or made generally available in another way." And, at 17 , the same view is readdressed that, "A basic characteristic of open scientific research is the fact that the results are made generally available by publishing them."

70 See Soons, supra note 22, at 46.

$71 \quad$ Ibid. 
condition." ${ }^{72}$ With the case of ocean measurements on vos as foregoing mentioned, it is suggested that the notifying regime can be used to substitute for the consent regime for several reasons. Firstly, it can be regarded that the measurements are conducted "exclusively for peaceful purpose and in order to increase scientific knowledge of the marine environment for the benefit of all mankind. Secondly, those measurements can hardly be counted as a large-scale marine scientific research project, which needs long time elaborate preparative work. They are merely the incidental products while those commercial vessels passing through the marine area. Thirdly, if conducting those measurements on the basis of coastal State's domestic law or Los Convention, the application procedure would be so prolonged and complicated that does no good for the sake of science development. Furthermore, once the delay of clearance request interferes with the research cruise, the quality of observation results would be definitely impaired since the cruise of the vos is usually regular and the observations are persistent as well. Viewed from these perspectives, accordingly, the clearance procedures probably can be omitted in order to saving time and increasing efficiency. Still, notifying must be given in advance because the coastal State is entitled to be acquainted with the situation.

In the meanwhile, other obligations and regulations those are fit for marine scientific research should be applied to the conduct of marine measurements on vos alike. In the light of Los Convention Article 248, the coastal State is entitled to be provided the full description of the name of the voluntary observing ship; the nature and objectives of the project; the method and means to be used; the precise geographical areas; the expected date of conducting research; the deployment of the equipment and its removal; the name of the sponsoring institution and the person in charge of the project; and the extent to which the coastal state is considered to be able to participate or to be represented in the project. Other than that, Article 249 addresses the duty to comply with certain conditions imposing on the research State, involving the right of coastal State to participate or be represented in the research project, and even more important is regarding the management of the research data, samples and results. These conditions are essential elements that could achieve balance between the interests of the coastal States and the international marine scientific community. ${ }^{73}$ In this respect, it is submitted that it may be more reasonable for the conduct of ocean measurements on vos that using notifying regime replaces the consent regime while all the other duties, guidelines and criteria are still as same as the regime of marine scientific research codified in Los Convention.

72 See Soons, supra note 22, at 160.

73 See Nordquist, supra note 44 , at 540. 


\section{$3 \quad$ Jurisdiction Issue}

In terms of vessels' jurisdiction issue on the sea, the allocation could be detected in reference to the functions of the State in the maritime context. Three players thus should be brought in mind which are respectively: flag State, whose flag is flown; coastal State along whose coasts shipping routes pass by; and port State, at whose ports or anchorages shipping calls. Combined then with the legal regime provided in the Los Convention in view of different marine areas, the jurisdiction issue, thus, would be considered in a comprehensive and reasonable way.

Flag State jurisdiction is the oldest expression of maritime jurisdiction. It is also coincidental to the jurisdiction that is exercised on the basis of nationality since ships are considered as a part of the national territory. ${ }^{74}$ Churchill and Lowe addressed that "the ascription of nationality to ships is one of the most important means by which public order is maintained at sea. As well as indicating what rights a ship enjoys and to what obligations it is subject, the nationality of a vessel indicates which State is to exercise flag State jurisdiction over the vessel." 75 In view of Article 91 of the Los Convention, "[e]very State shall fix the conditions for the grant of its nationality to ships, for the registration of ships in its territory, and for the right to fly its flag" and "There must exist a genuine link between the State and the ship."76 Furthermore, the International Tribunal on the Law of the Sea (IтLOS) clarified in the case of the M/V "Grand Prince" that if the domestic law of a State provides that the right of a ship to fly its flag is directly connected to the act of registration of the ship in that State, registration is the decisive factor with regard to the nationality of that ship. ${ }^{77}$ The extent of jurisdiction exercised by the flag State is summarily set out in Article 94 of LOS Convention. It comprises the obligation to

74 Maria Gavouneli, Functional Jurisdiction in the Law of the Sea 34 (2007). However, there is some debate as to the nature of flag State jurisdiction. Some authors regard that view that flag State jurisdiction is the jurisdiction of territoriality tends to be obsolete. The assertion what is more acceptable is that flag State jurisdiction should be considered a kind of jurisdiction suigeneris. Excerpted from HAIJIANG YANG, JURISDICtion of the coastal State over Foreign Merchant Ships in International WATERS AND THE TERritorial SEA 26 (2005).

75 R.R. Churchill and A.V. Lowe, The Law of the Sea 205 (1999).

76 The Convention, however, does not impart any solution to the basic problem concerning the definition of genuine link nor does it give any guidance on what conditions of registration would satisfy the "genuine link" requirement. See Rainer Vogel, Flag States and New Registries, in The Marine Environment and Sustainable Development: Law, Policy And Science (1993), at 421.

The $M / V$ "Grand Prince" (Belize v. France), It Los Reports 2001, 17 (paras. 83) 
effectively exercise jurisdiction and control in administrative, technical and social matters, ${ }^{78}$ including the construction, equipment and seaworthiness of ships; ${ }^{79}$ the manning of ships, labor conditions and the training of crews; ${ }^{80}$ as well as the use of signals, the maintenance of communications and the prevention of collisions. ${ }^{81}$ In the meanwhile, by virtue of paragraph 5 of Article 94 LOS Convention, ${ }^{82}$ " $[\mathrm{I}] \mathrm{t}$ becomes thus clear that the standards, which the State is called to uphold, are international rather than domestic - and consequently the ample facility to regulate the ship flying one's flag is in actual practice severely curtailed by globally agreed rules and regulations." 83

Having established the freedom of high seas (Article 87, Los Convention), it is clear that the order of the high seas was entrusted primarily to the flag State. Pursuant to Article 92, "[S]hips shall sail under the flag of one State only and, save in exceptional cases expressly provided for international treaties or in this Convention, shall be subject to its exclusive jurisdiction on the high seas." The flag State jurisdiction accordingly becomes "the cornerstone on which the public order of the high seas is erected. Consequently, the strength of the overall regulatory system would necessarily rest upon the effectiveness of flag State jurisdiction." 84 The so-called "exclusive jurisdiction," however, could be challenged by the circumstances of slave trafficking ${ }^{85}$ and piracy, ${ }^{86}$ which are both offences under universal jurisdiction. ${ }^{87}$ Any other intervention on a vessel on the high seas is strictly depended upon the primacy of flag State jurisdiction. ${ }^{88}$

In view of ocean measurements on vos on the high seas, the flag State jurisdiction is applied equally. The vos is protected on the high seas under international law by the flag State whose flag it is entitled, by registration, to fly. It is stated, "A vessel which is so registered and controlled enjoys a large degree of

\footnotetext{
78 Art. 94, para. 1, Los Convention.

79 Art. 94, para. 3(a), Los Convention.

8 o Art. 94, para. 3(b), Los Convention.

81 Art. 94, para. 3(c), Los Convention.

82 It is provided that, "In taking the measures called for in paragraphs 3 and 4 each State is required to conform to generally accepted in international regulations, procedures and practices and to take any steps which may be necessary to secure their observance."

83 Gavouneli, supra note 74 , at 35 .

84 Ibid., at 162.

85 Art. 99, Los Convention.

86 Art. 105, Los Convention.

87 Gavouneli, supra note 74 , at 159 . Other than slave trade and piracy, the stateless vessels are assumed to be equated to pirate or slave vessels, which are subject to universal jurisdiction as well. For the same view, also see A.W. Anderson, Jurisdiction over Stateless Vessels on the High Seas: An Appraisal under Domestic and International Law, 13 JoU RNAL of Maritime LaW and Commerce 336 (1982).

GAVOUNELI, supra note 74, at 161.
} 
immunity on the high seas from interference by the vessels of other States." 89 Furthermore, under Los Convention, the freedom of high seas comprises conducting scientific research as well as marine measurements on the high seas. It is therefore submitted that while vos passes through the high seas, the conduct of ocean measurements is under the exclusive jurisdiction of flag State. In the meanwhile, since it is under the freedom of high seas as well, no other States could exert intervention therein as long as the conduct is exercised with due regard for the interests of other States and also under the conditions laid down by the Los Convention and other rules of international law.

B

Exclusive Economic Zone - Concurrent Jurisdiction

Concurrent jurisdiction denotes that the competence is shared between the coastal State and other State. ${ }^{90}$ With respect to further grasp its connotation, the legal status of the EEZ should be first ascertained under the sight of international law, specifically the Los Convention. It is generally agreed that the exclusive economic zone constitutes a sui generis zone, neither a part of the high seas nor of the territorial waters. ${ }^{91}$ The "sui generis" legal character of EEZ has three principle elements, which are respectively (1) the rights and duties that Los Convention accords to the coastal State; (2) the rights and duties that Los Convention accords to other State; (3) residual rights or jurisdiction that are not fall within either of the two previous categories. ${ }^{92}$

Under Article 56 of Los Convention, the coastal State has acquired "sovereign rights" on the one hand and "jurisdiction" on the other. Rather the "sovereign right" and "jurisdiction" are exercised in a functionally limited way. ${ }^{93}$ While the sovereign rights are exercised with regard to exploring, exploiting, conserving and managing natural resources and other economic activities, the jurisdiction was granted over certain activities, namely the establishment and use of artificial island, installation and structures; marine scientific research; and the protection and preservation of the marine environment. Furthermore,

$89 \quad$ See Anderson, supra note 87 , at 335 .

90 For the sake of addressing the legal issue regarding vos, analysis that is relevant to "other State" would mainly focus on the "flag State."

91 The term "sui generis zone" was first used by the Chairman of the Second Committee of UNlos iII. See UnClos III, Official Records, Volume V 153 (1976). The terminology has been accepted by the leading textbooks on the field. See E.D. Brown, THE INTERNational LaW of the Sea, Volume I 218 (1994); Churchill and Lowe, supra note 75, at 166. The note excerpted from Alexander Proelss, The Law on the Exclusive Economic Zone in the Perspective: Legal Status and Resolution of User Conflicts Revisited, 26 OCEAN YЕАRBOOK 87-112 (2012).

92 Churchill ANd Lowe, supra note 75.

93 See Proelss, supra note 91. 
whereas the notion of "sovereign rights" signifies something less than sovereignty since it could only be exercised once an E EZ was proclaimed, ${ }^{94}$ "jurisdiction" denotes an even more restricted exercise of competence..$^{95}$ It is addressed that " $[t]$ he existence of sovereign rights creates a presumption of sovereignty for the coastal State which would supersede a jurisdiction claim by another State whereas claims of jurisdiction operate on the same level of equality and must be resolved through the standard dispute settlement procedures. ${ }^{96}$

The rights and duties of other States are set out in Article 58 of Los Convention, which was described by Maria Gavouneli as "less specific and certainly more comprehensive." 97 They are primarily concerned with those freedoms expressly provided in Article 87 (freedom of high seas), namely the freedom of "navigation and overflight and of the laying of submarine cables and pipelines, and other internationally lawful uses related to these freedom," with the exception of the freedom of fishing, which has become a sovereign rights of the coastal State and other related topics, including conduct marine scientific research as well as construct artificial islands and other installations. The "other internationally lawful uses," which are demanded to be "compatible with other provisions of this Convention," include, inter alia, "those associated with the operation of ships, aircraft and submarine cables and pipelines." 98 It is notable that, however, these freedom exercised by other State in EEZ are subject to measures relating to sovereign rights of the coastal State ${ }^{99}$ as well as the general limitation governing all freedoms of the high seas.

As for the concurrent jurisdiction in the EEZ, which strikes a balance between the coastal State and other States, signifies the true nature of the EEZ. The coastal State and flag State which are endowed respectively with varied rights and duties can be assumed as two parallel players in maintaining the order of the EEz. The fact that certain activities in the EEz either fall within the jurisdiction of the coastal State or the flag State justifies the consent regime with regard to marine scientific research conducted in EEZ and the navigation freedom of foreign commercial vessels, which are engaging maritime

94 Gavouneli, supra note 74 , at $64-65$.

95 Ibid.

$96 \quad$ Ibid.

$97 \quad$ Ibid.

98 Nordquist, supra note 44 , Volume II, at 564 .

99 Ibid., at 565 . Article 58 , para. 3 of the Los Convention stipulated that "In exercising their rights and performing their duties under this Convention in the exclusive economic zone, States shall have due regard to the rights and duties of the coastal State and shall comply with the laws and regulations adopted by the coastal State in accordance with the provisions of this Convention and other rules of international law in so far as they are not incompatible with this Part." 
commerce whilst passing through the coastal State's EEz. With respect to the conduct of ocean measurements on vos, as stated earlier, it constitutes marine scientific research and thus is theoretically subjected to the coastal State's jurisdiction. Due to the measurements are conducted during the course of passage through the coastal State's EEZ, those vessels, mostly commercial vessels, who have the freedom of navigation therein practically exercise real control over the conduct. Additionally, the consent regime has limited enforcement power in terms of the ocean measurements on vos since it is not, as foregoing, necessarily applied to those measurements. Under the notification regime, other than the duties which are contained in the Los Convention in Part XIII, which includes, providing information to the coastal State as well as complying with certain conditions, the researching State still needs to give advance notice to the coastal State. It is no other than the particular peculiarity, namely, incidental measurements, which do not constitute complex research project, combined with the freedom of navigation as well as the application of notifying regime, signifies that the vessels could exercise, to a certain degree, control over the measurements on vos. That is to say, in the light of the flag State jurisdiction theory, the flag State is entitled some jurisdiction as well. Nevertheless, such category of jurisdiction can only be deemed as a complement to the coastal State jurisdiction when it cannot be exercised promptly or effectively. In that case, the flag State complements the coastal State in exercising jurisdiction over the ocean measurements on vos, together constitute the essence of concurrent jurisdiction in the regime of the EEz.

C Territorial Sea - Coastal State Jurisdiction

Pursuant to Los Convention Article 2, the sovereignty of a coastal State extends to the territorial sea, which refers to the maritime waters stretching seaward from the baseline. The concept of coastal State sovereignty over the territorial sea was accepted, for the first time, at UNCLOS I, which was held in Geneva in April 1958, ${ }^{100}$ as conventional international law. ${ }^{101}$ At UNCLOS III, the debates were more on the limits than on the legal status of the territorial sea. ${ }^{102}$ Eventually, under Los Convention, the coastal State's sovereignty over the territorial sea was retained as well as the breadth of the territorial sea up to the maximum limit not exceeding 12 nautical miles even though in State practice the diversity of the breadth still exists. ${ }^{103}$ Furthermore, the exercise of coastal State's sovereignty over its territorial sea is subject to the

\footnotetext{
100 UNCLOS I, OfFicial Records, Vol. I, at 1.

101 YANG, supra note 74, at 121.

102 Ibid., at 123.

103 Ibid., at 124.
} 
right of innocent passage, which assumed as the main restriction, compared with sovereignty over the land territory, imposed by international law. It can be asserted therefore that the right of innocent passage has been introduced to dilute the sovereignty of the coastal State in order to facilitate the navigational right of all other States. Nevertheless, the right of innocent passage can never be taken as equivalent to the freedom of navigation in the EEZ or on the high seas, either in content or extent. It is conferred the right to the coastal State that "take the necessary steps in its territorial sea to prevent passage which is not innocent." 104 And any contravention of the laws and regulations of the coastal State would expose the ships to potential punishment. ${ }^{105}$ As far as the definition of "innocence" is concerned, the Los Convention in Article 19, Para. 1 provided that so long as the passage "is not prejudicial to the peace, good order or security of the coastal State" as well as "take place in conformity with this Convention and with other rules of international law," it is then innocent. Rather, Article 19, Para. 2 goes further to enumerate twelve types of conduct which would be "prejudicial" to the peace, good order or security of the coastal State and therefore render the passage non-innocent. ${ }^{106}$

Having clarified the denotation of "innocent," the meaning of "passage" attaches more weight to analyze the legal issues of ocean measurements on vos. The Los Convention provides the definition of passage in Article 18, which consists of two categories: lateral passage and passage to or from a call at port facility either inside or outside internal water, within the context of the right of innocent passage. ${ }^{107}$ Both of these two forms of passage are of great relevance to the analysis of measurements conducted on vos. While the lateral passage signifies the passage without entering internal waters, which is the typical and traditional type in the context of innocent passage, the passage to or from a port facility either inside or outside internal waters might be aroused by "the desire to facilitate international navigation and trade on the one hand, and correspondingly, to contain coastal State jurisdiction over such passage operation on the other."108 It is thus, compared with lateral passage,

\footnotetext{
104 See Art. 25 para.1, Los Convention.

105 YANG, supra note 74 , at 147.

106 With respect to the list of activities in Para.2 of Article 19, the US and the former USSR hold the connotation in an agreement that "Article 19 of the Convention of 1982 sets out in paragraph 2 an exhaustive list of activities that would render passage not innocent. A ship passing through the territorial sea that does not engage in any of those activities is in innocent passage." It is believed, contrarily, by Haijiang Yang that Para.2 only purported to exemplify the vague expression of the concept of innocent passage. By no means is Para. 2 designed to exhaust all cases in which passage would be rendered non-innocent. YANG, supra note 74 , at 159-160.

107 YANG, supra note 74, at 151.

108 Ibid., at 151.
} 
more vulnerable. ${ }^{109}$ In respect of coastal State jurisdiction, passage to or from a port facility depends completely upon the permission of the coastal State and therefore is more likely to be susceptible of the interference by the coastal State. ${ }^{110}$ It is consequently submitted that, in the territorial sea, the coastal State jurisdiction always maintains the primacy; even under the regime of innocent passage it is still highly subjected to the coastal State's jurisdiction.

On account of the ocean measurements on vos, it can fit both two categories of passage, either lateral passage or the passage to or from port facility. In the case of passage to or from port facility, it will become relevant to the issues of internal waters jurisdiction and port State jurisdiction, which will be dealt with later. In pursuance of Article 19 para.2 of the Los Convention, carrying out survey activities or research would render the passage non-innocent. Moreover, under Article 25 the coastal State may take the necessary steps to prevent passage, which is not innocent. Due to that the Convention is keeping silent on declaring what "the necessary steps" should be, it is completely within the discretion of the coastal State to decide what steps should be taken. ${ }^{111}$ Given that the foreign ships would fully fall under coastal State's jurisdiction if the passage is not innocent anymore, ${ }^{112}$ the conduct of carrying out ocean measurements on vos while the vessels are passing through the territorial sea, either in lateral passage or heading to the port facility, will fully fall within the coastal State's jurisdiction. The proposed "notifying regime" could mitigate in no way the obligation to observe the coastal State's jurisdiction, except only simplifying the clearance procedure, which for the sake of promoting science development as well as the benefit of all the mankind. Consequently, the conduct of ocean measurements on vos should comply with the laws and regulations that adopted by the coastal State and that in the meantime fully subject to the administrative jurisdiction of coastal State.

Compared with the territorial sea, the absence of the right of innocent passage comprises the principal distinction of the internal waters. ${ }^{113}$ Pursuant to Article 8 of Los Convention, waters, except as provided in Part IV (Archipelagic

\footnotetext{
$109 \quad$ Ibid., at 151.

$110 \quad$ Ibid., at 151.

111 Ibid., at 217.

112 ChURCHILl AND Lowe, supra note 75 , at 87.

113 With the exception of the case that, according to Article 8 para.2, however, where the establishment of a straight baseline in accordance with the method set forth in Article 7 has the effect of enclosing as internal waters area which had not previously been considered as such, a right of innocent passage as provided in Los Convention shall exist in those waters.
} 
States), on the landward side of the baseline of the territorial sea form part of the internal waters, which normally comprises different kinds of waters, like bays, estuaries and ports, rivers and lakes. ${ }^{114}$ They are deemed as an integral part of the territory of a coastal State and subject to the same legal regime as its land territory. The coastal State enjoys full territorial sovereignty over them. The issues with regard to the right of access to ports and the exercise of jurisdiction over foreign ships in ports have been always surrounded by severe controversies. Nevertheless, coastal State, in practice, generally admits foreign ships to their maritime ports and waterways that are open to international trade and navigation. ${ }^{115}$ Whereas there is no general right of entry exists in customary law, 116 it is granted under treaty laws, which are most commonly bilateral treaties or multilateral Convention and Statute on the international level. ${ }^{117}$ Under Los Convention, it is implied that land-locked State enjoys the right of access to ports in Part $\mathrm{X}$ as well as Article 211 (3) provides that the coastal State shall give due publicity to those requirements, which are considered as conditions for the entry of foreign vessels into their ports or internal waters or for a call at their off-shore terminals. ${ }^{118}$ With respect to the jurisdiction issue in internal waters, it is settled since the moment that the vessels enter coastal State's port and internal waters because they put themselves within the territorial sovereignty of the coastal State. The coastal State is entitled to enforce its laws and regulations against foreign vessels, ${ }^{119}$ even though coastal State commonly enforce their laws and regulations only when its interests are endangered. ${ }^{120}$

A port State is always a coastal State, although the reverse is not always true. ${ }^{121}$ "The creation of a separate port State jurisdiction is the direct consequence of the expansion of the coastal State's jurisdiction over the exclusive economic zone, especially in view of the enhanced environmental protection provisions included in the LOS Convention." 122 It can be seen thus that the port State jurisdiction, as the innovation of the enforcement system within the context of Convention, ${ }^{123}$ was introduced on account of the increasing importance of marine environmental protection. With respect to the innovational

\footnotetext{
114 ChURChill AND Lowe, supra note 75.

115 YANG, supra note 74, at 48.

116 CHURCHILl AND Lowe, supra note 75 .

117 Ibid. See also YANG, supra note 74, at 56-6o.

118 YANG, supra note 74 , at 59.

119 CHURCHILl AND LOWE, supra note 75 .

120 Ibid.

121 GAVOUNELI, supra note 74, at 44.

122 Ibid.

123 NoRDQUIST, supra note 44, at 260.
} 
feature of port State jurisdiction, it is stated that "[t]he big difference lies in the "voluntary" character of the ship's presence in port. Whereas the principle of innocent passage shields the seagoing vessel from the jurisdiction of the coastal State, port State jurisdiction strengthens compliance with national rules and regulations without any interference with the freedom of navigation since entry into a port constitutes a voluntary submission of the vessel to the jurisdiction of the port State - either and both running concurrently with the original jurisdiction of the flag State."124

Coming then back to the ocean measurements on vos, as those vessels voluntarily enter a port or internal waters of the coastal State, they accordingly put themselves under the jurisdiction of the coastal State. Given the practice that coastal State enjoys the discretion to leave the matters relating purely to internal affairs of the vessel to the authorities to the flag State, ${ }^{125}$ foreign vessels are, to a certain extent, still subject to the jurisdiction of flag State. Nevertheless, local jurisdiction will be exercised when the activities affect the peace or good order of the port. ${ }^{126}$ Ocean measurements conducted within the internal waters without consent, which is normally deemed as holding a prejudice against the peace and good order of the port cannot be allowed in any country, unless otherwise regulated by treaty between the coastal State and the flag State. Despite the application of notifying regime to the special case, namely ocean measurements on vos when the vessels bound for the ports of coastal State passing through the territorial sea, coastal State jurisdiction still will be asserted over the measurements, as much as within the territorial sea.

\section{$4 \quad$ Other Emphasis}

In view of marine scientific research under Los Convention, a lot of efforts have been made to strike a balance between the interests of the coastal State and the marine scientific community, which is primarily in Article 249. It provides access for the coastal State to all data, samples and research results as well as the assessment concerned and make the publication, and dissemination of information and knowledge through appropriate national or international channels. While the Los Convention actively promotes the flow of scientific data and information and the transfer of knowledge resulting from marine scientific research, ${ }^{127}$ it still should be noted that regarding the research results of a project which is of direct significance for the exploration and exploitation of natural resources,

\footnotetext{
124 GAVOUNELI, supra note 74, at 44.

125 ChURCHILl AND Lowe, supra note 75. See also YANG, supra note 74, at 84.

126 CHURCHILl AND LowE, supra note 75.

127 See Art. 244, Los Convention.
} 
the prior agreement for making the results internationally available should be required. ${ }^{28}$

It is also guided by the general provision that States and competent international organizations shall promote and facilitate the development and conduct of marine scientific research in accordance with the Los Convention. ${ }^{129}$ In order to do so, all States shall promote international cooperation as well as create favorable conditions for the conduct of marine scientific research. ${ }^{130}$ Ocean measurements on vos, which are conducted exclusively for peaceful purposes and for the benefit of all humankind, therefore should be promoted. Other than that though, the researching State should, if requested so, provide access of the research data, sample and result to the coastal State. Meanwhile, technical assistance through meaningful cooperation should be encouraged as well.

\section{Summary}

In light of the ever-increasing degree of ocean uses, which specifically point to ocean measurements on vos, this article intends to review the legal status of the conduct by analyzing the fundamental legal regime of marine scientific research under the Los Convention. More importantly, it re-examines the implementation of the Los Convention and the potential ways for the resolution of conducting ocean measurements on vos, which constitute marine scientific research, while the vessels are passing through the EEZ, territorial sea and internal waters where the coastal State enjoys jurisdiction, sovereign rights and sovereignty, respectively. Based on the special peculiarity of ocean measurements on vos, compared with the consent regime that applies in Part XIII (marine scientific research) of the Los Convention, the notification regime is suggested to introduce on account of practical considerations and convenient clearance procedures. In spite of the simplified clearance procedures, the rights and obligations that are vested due to the establishment of various marine areas by the Los Convention and the legal regime of jurisdiction therein are still bound to be observed. Furthermore, as far as marine scientific research is concerned, legal regulations, which are provided in the Los Convention in Part XIII, are likewise applicable.

\footnotetext{
128 See Art.249, Los Convention.

129 See Art. 239, Los Convention.

130 See Arts. 242 and 243, Los Convention.
} 